\title{
ナイロン 6/芳香族ポリアミドブレンドフィルムのカ学物性と構造
}

\author{
大浦 純一*1 ・ 柴山 充弘*1 ・櫻井 伸一*1 ・ 野村 春治*1 ・岩本 壮弘*2
}

（受付 1996 年 3 月 26 日・審査終了 1996 年 4 月 12 日）

\begin{abstract}
要 旨 ナイロン $6(\mathrm{Ny}$ 6) と芳香族ポリアミドであるポリメタキシレンアジパミト (MXD) からなる2成分フ レンドフィムの引き裂き性と構造の関係について報告する. フレンド武料の引き裂きのずれおよひ荷重は, 引き 裂き方向が機械の押出し方向 (MD) の場合と, その垂直方向 (TD) の場合で差が生じた，ホモポリマーではこのよ うな差はなかった. また, TEM 観察の結果, フレンド武料はMDに連続相を成す細長い MXD ドメインが Ny 6 マ トリックス中に存在している構造であることが分かった。この異方的なドメイン形状が，引き裂き性の MD と TD における差の原因であると考えられる.
\end{abstract}

\section{1 楮言}

既存の物質から新しい材料を得るために，ポリマーブ レンドは有用な手法である. 特に, 結晶性ブレンドの場 合には非晶性ブレンドに比べて力学的, 熱的性質に優れ た材料が得られるために,さまざまな応用研究が行われ ている. そのうちの一つに, 結晶性ポリマーであるナイ ロン 6 と他の結晶性/非晶性ポリマーからなる種々のブ

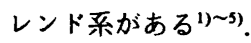

本研究で取り扱う試料は, ナイロン 6 ( Ny 6) と芳香 族ポリアミドであるポリメタキシレンアジパミド (MXD) を溶融混練して得られた 2 成分ブレンド試料で ある. 両成分の構造式を Fig. 1 に示す. Ny 6 と MXD は共に結晶性ポリマーである。

MXD はNy 6 に比べて弾性率, ガスバリアー性が高 い.一方, Ny 6 は MXD よりも延性が高い.すなわち, これらの 2 成分を混ぜ合わせることにより, 互いの弱点 を補い合った材質を得ることが可能である. 実際に, フィルム状に加工した Ny 6/MXD ブレンド試料の力学 試験における破断伸度はNy 6 ホモポリマーのそれに匹 敵するほど高く，酸素透過率はNy 6 ホモポリマーフィ ルムに比べて低い.つまり，Ny 6 の延性を損なうこと なく，MXDの高いガスバリアー性がブレンド試料中に おいても発揮されている.このことはブレンドによるカ 学的性質とガスバリアー性の相互補完がうまく行われて いることを示している.

本系はまた, 反応性ブレンドであることが過去の研究

*1 京都工芸䋖維大学䋐維学部（\$606 京都市左京区松ヶ崎御 所海道町)

* 出光石油化学(株)製品部（-672 姫路市白浜町甲 841-3）
から知られている( ${ }^{6)}$. すすなわち, 両成分の融点以上の 高温で数十分から数時間の熱処理を行うことによって, 分子鎖中のアミド基の切断・再結合が起こり, 試料の一 部またはほぼ全体がコポリマー化する.

そして新たな性質として, フィルム状のブレンド試料 を引き裂いた場合, 引き裂き進行の直進性がフィルムの

\section{Nylon $6(N$ y 6$)$}<smiles>CC(C)(C)C(C)(C)CCCCN</smiles>

$\mathrm{Mn}=23,000, \mathrm{Tm}=220^{\circ} \mathrm{C}, \mathrm{Tg}=51^{\circ} \mathrm{C}$

Poly(m-xylene adipamide) (M X D)<smiles>CC(C)CCC(=O)Nc1ccc(CN(C)C)cc1</smiles>

$\mathrm{Mn}=25,000, \mathrm{Tm}=235^{\circ} \mathrm{C}, \mathrm{Tg}=83^{\circ} \mathrm{C}$

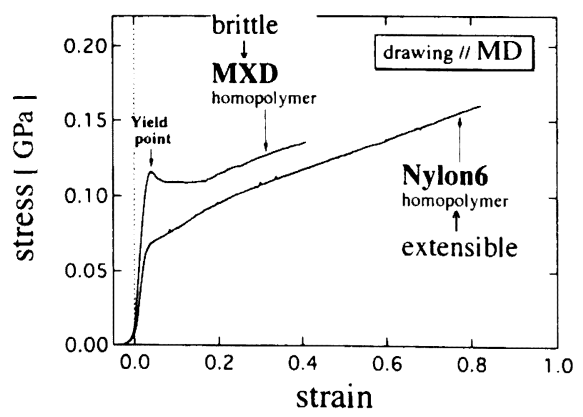

Fig. 1. Structural formulae of homopolymers and stress-strain results for homopolymer films. 
方向によって異なることが発見された．また，MXDが 分散相であるブレンドフィルムにおいて, MXDドメイ ンは太さ数百 $\mathrm{nm}$, 長さ数千 $\mathrm{nm}$ の細長い形状をしてお り一定方向に配列していることが電子顕微鏡観察から分 かった. そして, 細長いMXDドメインの長さ方向に 沿って引き裂いた場合はまっすぐに裂けるが，この方向 と垂直方向に引き裂こうとすると斜めにずれて引き裂き が進行する，という傾向が観察された。 ホモポリマー フィルムにおいてはこのような引き裂き異方性は見られ

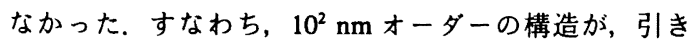
裂き性というマクロな力学的性質に顕著な影響を及ぼし ていると予想される.

そこで, 本研究では二軸延伸フィルムの引き裂き異方 性およびブレンド組成依存性と, ドメイン構造の関係を 解明することを目的とし, 力学試験, 透過型電子顕微鏡 (TEM) 観察および静的光散乱法による実験および解析 を行った.

\section{2 実験}

\section{1 試料}

ブレンド試料の作製に用いたホモポリマーはNy 6 (宇部興産 (株)製,グレードNo.1023) とMXD（三菱 ガス化学(株)製，グレードNo. 6007）である. それぞ れの構造式, 数平均分子量 $M_{n}$, 融点 $T_{m}$, ガラス転移温 度 $T_{\mathrm{g}}$ を Fig. 1 に示す. ホモポリマーはサイズが数 $\mathrm{mm}$ のペレット状である. 真空回転乾燥機中で温度 $110^{\circ} \mathrm{C}$, 真空度 3 Torr の条件で約 5 時間の乾燥を行った後, 溶 融混練に用いるまで密閉保存した.

ペレット状ホモポリマーを種々の分率で混ぜ合わせて 工業用溶融混練機に入れ, 溶融混練した. 混合比は重量 分率で Ny 6/MXD =0/100, 60/40, 70/30, 80/20, 90/10, 100/0 である.この割合を試料の組成比とする．混練機 内の温度は約 $275^{\circ} \mathrm{C}$ に保たれており, 混練時間は 1 分 以内, 混練スクリュ一回転数は $125 \mathrm{rpm}$ とした. 混練機 から押し出された溶融状態のポリマーはローラーによっ て厚さ約 $160 \mu \mathrm{m}$ のフルム状に成形される.この段階 で採取したフィルムを未延伸フィルムと呼ぶ。また, フィルムの機械押出し方向をMD, 幅方向（MDに垂 直方向）をTD, そしてフィルム面の法線方向を NDと 定義する.

続いてチューブラー法による同時二軸延伸を行っ だ). 延伸倍率は MD, 3.5 倍；TD, 3.0 倍である. 延伸 は試料を加熱しながら行った. 加熱ヒーター温度は $310^{\circ} \mathrm{C}$, フィルム温度は約 $100^{\circ} \mathrm{C}$ で, 両ホモポリマーの $T_{8}$ 以上で延伸が行われていると考えてよい．このよう にして得られたフィルムを二軸延伸フィルムと呼び, 本 研究の測定試料として用いた. 本文中, 特に断りがない 場合, フィルムは二軸延伸フィルムを指すすのとする.
二軸延伸フィルムの厚さはどの組成についても約 $16 \mu \mathrm{m}$ であった. 未延伸フィルム, 二軸延伸フィルムの両方之 あ作製後はシリカゲルとともにガラス容器内に保管し, 吸湿防止につとめた。

なお，MXD リッチの組成については，フィルム成形 加工性が著しく悪いために作製できなかった。 ただし， MXD ホモポリマーについては延伸が可能であり二軸延 伸フィルムを得ることができた。 また，フィルムの端 （TDで見たときの左右端）付近は機械の構造上，延伸 状態が不安定になりやすくフィルム厚の不均一が生じや すいので, 測定試料片はフィルム中央から採取した.

\section{2 引張試験}

引張試験機にはオリエンテック(株)製 TENSILON/ UTM-II-5H を用い, 試料幅 $5 \mathrm{~mm}$, 測定試料長 $20 \mathrm{~mm}$, チャック移動速度 (引張速度) $10 \mathrm{~mm} / \mathrm{min}$, 室温で測定 を行った.フィルム厚をマイクロメーターを用いて一っ の試料片について数力所計湘し，その平均値を測定断面 積の計算に用いた. 試料片をガラス容器から取り出して から測定終了までの時間は数分であり，吸湿による影㫪 はほとんどないと思われる.

\section{3 引き裂き試験}

Fig. 2 に測定用試料の形状, 引き裂き荷重, 引き裂き 方向に対して垂直方向へのずれの測定方法を示す. あら かじめ試料片に切り目を入れておく：二つに割れた一方 の端を引張試験機の上側のチャックに, あう一方の端を 下側のチャックに取り付ける. そしてチャックの移動に より引き裂きを進行させて, 荷重を検出する. 引張試験 機にはオリエンテック(株)製 TENSILON/UTM-II-5H を用い, 室温, チャック移動速度 (引張速度) $50 \mathrm{~mm} /$ $\min$ すなわちフィルム引き裂き速度 $25 \mathrm{~mm} / \mathrm{min}$ で湘定 を行った. 引き裂き荷重をフィルム厚で割った値を $F$ [N/mm] と定義する. また，引き裂き方向が $\mathrm{MD}$ と平 行な場合を MD 引き裂き, TD と平行な場合を TD引き 裂きと定義する．測定時間は数分であり，吸湿による影 響はほとんどないと思われる。

また, Fig. 2 に従って引き裂き方向に対して垂直方向 へのずれ； $Y$ を定義する. 引張試験機による測定終了後 の試料片について, 引き裂き進行距離 $X$ における $\boldsymbol{Y}$ を ノギスを用いて測定した。

\section{4 透過型電子顕微鏡 (TEM) 篗察}

試料を $\mathrm{RuO}_{4}$ 䒺囲気下で染色し，マイクロトームを用 いて超薄切片を切り出し, 電子顕微鏡観察を行った.

\section{5 光散乱実験}

$\mathrm{He}-\mathrm{Ne}$ レーザー光によるフィルムの散乱像を, 自作 装置を用いて撮影した。偏光子 $(P)$ および検光子 $(A)$ の偏光方向は共に鈶直方向であり $V_{\mathbf{v}}$ 像を得る. スク リーンに映し出された像を裹面よりカメラ撮影した.

散乱光強度測定にはOPTEC (株)製レーザー光散乱測 
< sample >

film thickness ; $16 \pm 0.5[\mu \mathrm{m}]$
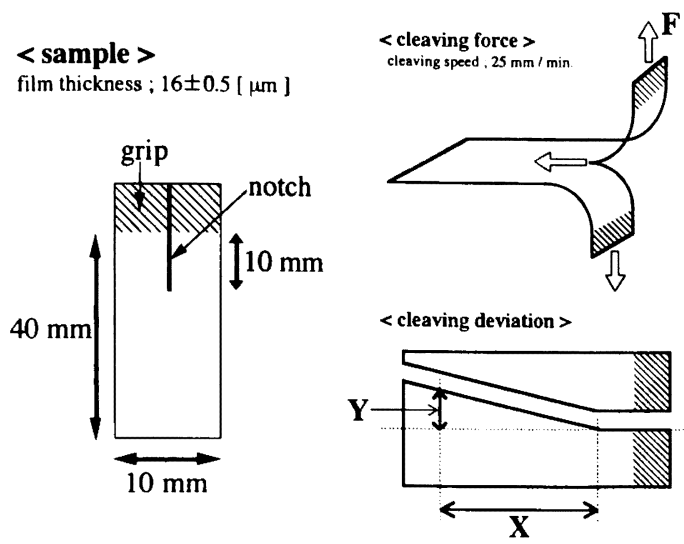

Fig. 2. Schema of the cleaving measurement.

定装置 GP-5DA を用いた。散乱角 $\theta$ 方向にヘッド部が 動く。へッド上部に取り付けた検出器（フォトダイオー ド）によって, 散乱角 $\theta$ における散乱光強度 $I(\theta)$ を計 測した. 一つの試料について場所を変えて 10 回の計測 を行い, その平均值をデータとして用いた，得られた散 乱データの有効と思われる $\theta$ 範囲に対して, 理論式に 従ってフィッティングを行い，MXDドメインサイズを 算出した

\section{3 桔果}

\section{1 木モポリマーの力学的性質}

Fig. 1 にNy 6 ホモポリマー $(\mathrm{Ny} 6 / \mathrm{MXD}=100 / 0)$ お よびMXD ホモポリマー $(\mathrm{Ny}$ 6/MXD=0/100) の引張 試験の結果を示す。両試料を比較した場合, ヤング率お よび降伏点応力は MXD の方が高く, 破断応力および 破断伸度はNy 6 の方が高い，すなわち，ブレンドフィ ルム中において MXD が脆性成分, Ny 6 が延性成分之 して作用していると考えられる.

\section{2 引き裂き性の速度依存性}

引き裂き性の引き裂き速度依存性 ${ }^{10)}$ を検討するため に, Ny 6/MXD =60/40 二軸延伸フィルムについて, 引

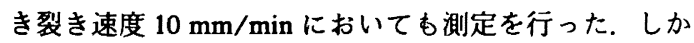
し, 引き裂き速度 $25 \mathrm{~mm} / \mathrm{min}$ の場合と比べて, $F$ の平 均値 $F_{\text {ave }}$ および引き裂き距離 $30 \mathrm{~mm}$ における $Y ; Y_{30}$ に 有為な差は観察されず, 本研究の範囲内では引き裂き速 度依存性は観察されなかった。

\section{3 引き裂き荷重および直進性}

Fig. 3 に $F$ の測定結果の一例を示す. グラフの縦軸は $F$, 横軸は引き裂き距離 $\boldsymbol{X}$ である。この結果から， $\boldsymbol{X}$ 全 体に渡る $F$ の平均值 $F_{\mathrm{ave}}$ を求めた. $\mathrm{MD}$ 引き裂きにお ける $F$ の平均値を $F_{\mathrm{ave}, \mathrm{MD}}, \mathrm{TD}$ 引き裂きにおける $F$ の平 均値 $\boldsymbol{F}_{\mathrm{ave}, \mathrm{TD}}$ と定義する. ホモポリマーフィルムでは有
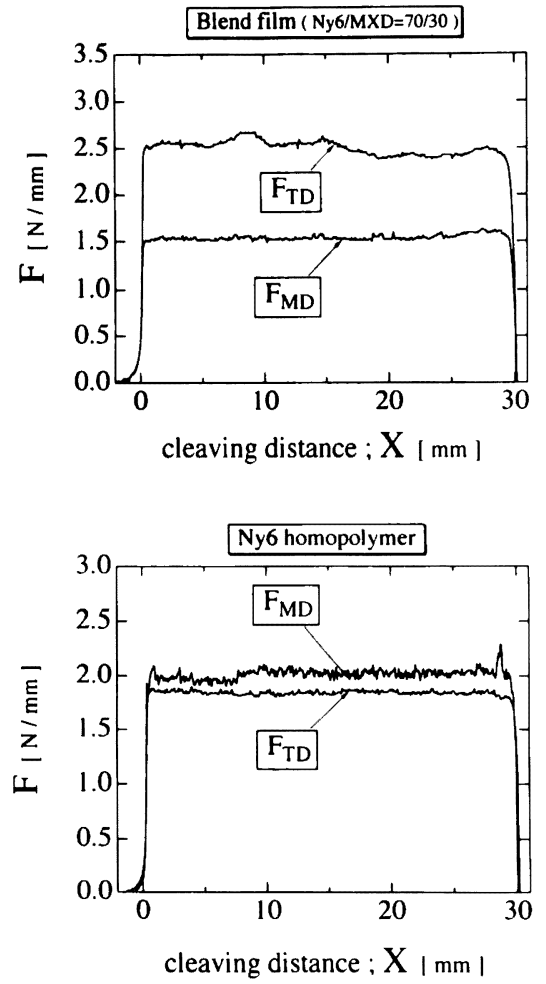

Fig. 3. Cleaving force per thickness vs. cleaving distance.

為な差が見られなかったのに対し，ブレンドフィルムで

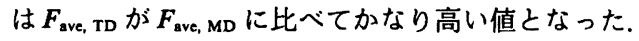

Fig. 4 に $Y$ の測定結果の一例を示す. 縦軸は $Y$, 横軸 は $X$ である. 1 種類の試料につき 5 回以上測定を行っ ており,グラフにはその平均値を掲載した，MD引き 裂きにおける $Y$ の値を $Y_{\mathrm{MD}}, \mathrm{TD}$ 引き裂きにおける $Y$ の 值 $\boldsymbol{Y}_{\mathrm{TD}}$ と定義する。 ホモポリマーフィルムでは有為な 差が見られなかったのに対し，ブレンドフィルムは $Y_{\mathrm{TD}}$ が $\boldsymbol{Y}_{\mathrm{MD}}$ に比べて大きい值となった. $\boldsymbol{Y}$ の值が大きいと いうことは，それだけ引き裂きの直進性が悪いというこ とである.

Fig. 5 に組成による $F_{\text {ave }}$ (上図) および $X=30 \mathrm{~mm} に$ おける $\boldsymbol{Y} ; \boldsymbol{Y}_{30}$ (下図) の組成による変化を示す. 上図の 程軸は $F_{\text {ave }}$, 横軸はNy 6 の重量分率; $\Phi_{\mathrm{Ny} 6}$ である. 1 種類の試料につき 5 回以上測定を行った. ブレンドフィ ルムはどの組成においても $F_{\text {ave, TD }}$ が $F_{\text {ave, MD }}$ に比べて高 い値となった。

下図の縦軸は $\boldsymbol{Y}_{30}$, 横軸は $\Phi_{\mathrm{Ny} 6}$ である. MD, TD 引 き裂きにおける $\boldsymbol{Y}_{30}$ の值をそれぞれ $\boldsymbol{Y}_{30, \mathrm{MD}}, \boldsymbol{Y}_{30, \mathrm{TD}}$ と定 義する．ブレンドフィルムはどの組成においても $Y_{30, \mathrm{TD}}$ が $\boldsymbol{Y}_{30, \mathrm{MD}}$ に比べて高い值となった。 つまり,ブレンド 

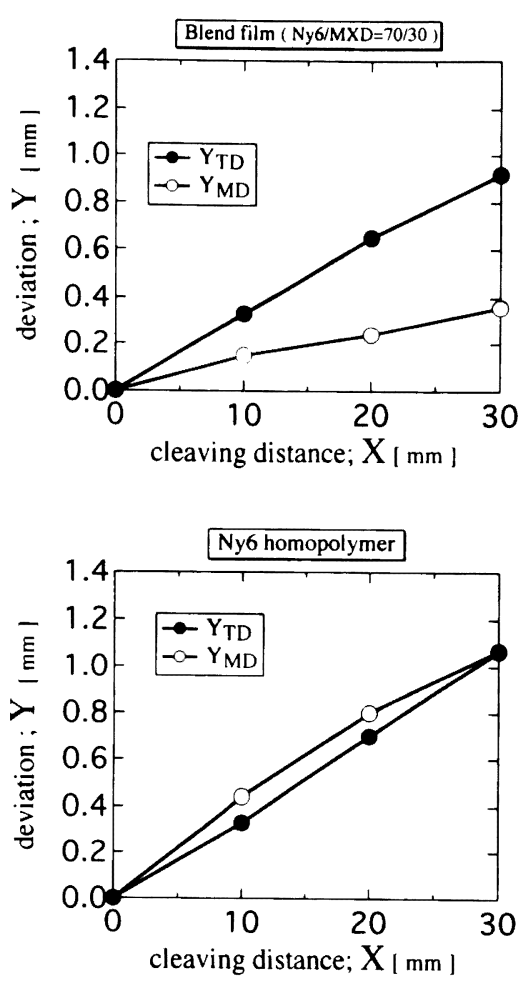

Fig. 4. Cleaving deviation vs. cleaving distance.

フィルムは MD にはまっすぐ裂けるが，TDに裂こうと すると横にそれるという傾向を示している.

\subsection{TEM 観察}

Fig. 6 はすべての二軸延伸ブレンドフィルムについて の TEM 写真である. $\mathrm{RuO}_{4}$ による染色機構は明らかで はないが, 組成による像の変化から, 暗部が Ny 6, 明 部が MXD の領域であると判断した. この Fig. 6 のよ うに edge view および end view を定義する. edge view 観察の結果から，二軸延伸フィルムでは MXDドメイ ンがMDに連続な相を形成しているのが分かる。また, end view 観察の結果から，MXD ドメインは細長い板状 であり,フィルム面に対して面配向している様子が分か る.

末延伸フィルムに対しても TEM 観察を行った. その 結果, 未延伸の段階ですでに MXD ドメンの MDの 連続性が観察された。 よって，末延伸フィルムにおける ドメインの連続性は, 混練・成形加工中に生じると考え られ, 二軸延伸後もその連続性は保持されている(1), 12).

Fig. 7 は Fig. 6 から推察された二軸延伸ブレンド フィルムのドメイン構造を考慮した引き裂きのモデルで ある.ブレンドフィルムのドメイン構造は, Ny 6 マト リックス中に細長いMXDドメインが規則的に配向し
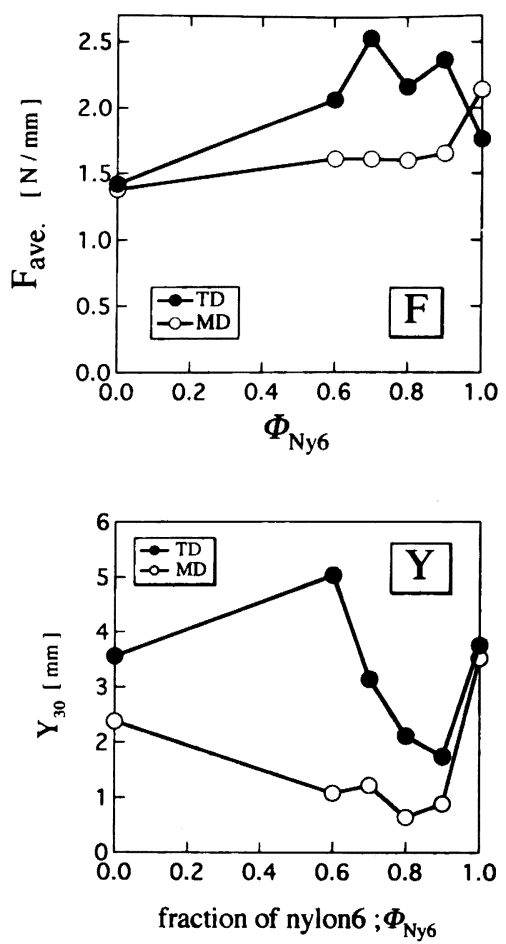

Fig. 5. Cleaving force per thickness vs. weight fraction of $\mathrm{Ny} 6$, and cleaving deviation at $X=30$ [mm ] vs. weight fraction of $\mathrm{Ny} 6$.

たものであると結論できる. MXD ドメインのサイズは 幅 $(/ / \mathrm{TD}) \sim 10^{2}[\mathrm{~nm}]$, 長さ $(/ / \mathrm{MD})>10^{3}[\mathrm{~nm}]$ である.

\section{5 光散乱実験}

Fig. 8 は $V_{v}$ 散乱像写真の一例である.レーザー光を フィルム面に垂直入射して得られた像である. 中心の暗 部はセンタービームストッパーの影である. ホモポリ マーでは等方的な散漫散乱のみであるのに対し, ブレン ド試料では TDにストリーク散乱が観察された. このス トリークは, MXDドメインの MDに伸びた異方的形 状を反映している.

また, $H_{\mathrm{v}}$ 像の観察も行ったが, 球晶の存在を示すよ うなクローバーパターンは見られなかった12).

Fig. 9 はストリークに沿って散乱光強度を測定した結 果である，縌軸は検出器（フォトダイオード）の電圧変 化すなわち散乱強度 $I(\theta)$, 横軸は散乱角 $\theta$ [degrees] で ある. 光学系は写真撮影と同様であり, 偏光子および検 光子は $V_{、}$ の位置, レーザー光を試料フィルム面に垂直 入射する. この結果に理論式によるフィッティングを行 い, TDでの MXDドメインサイズを求める. MXDド メインの完全配向を仮定した場合, 散乱光強度は次式の ように表される9). 
ナイロン6/芳香族ポリアミドブレンドフィルムの力学物性と構造

\section{< TEM : biaxially stretched film >}
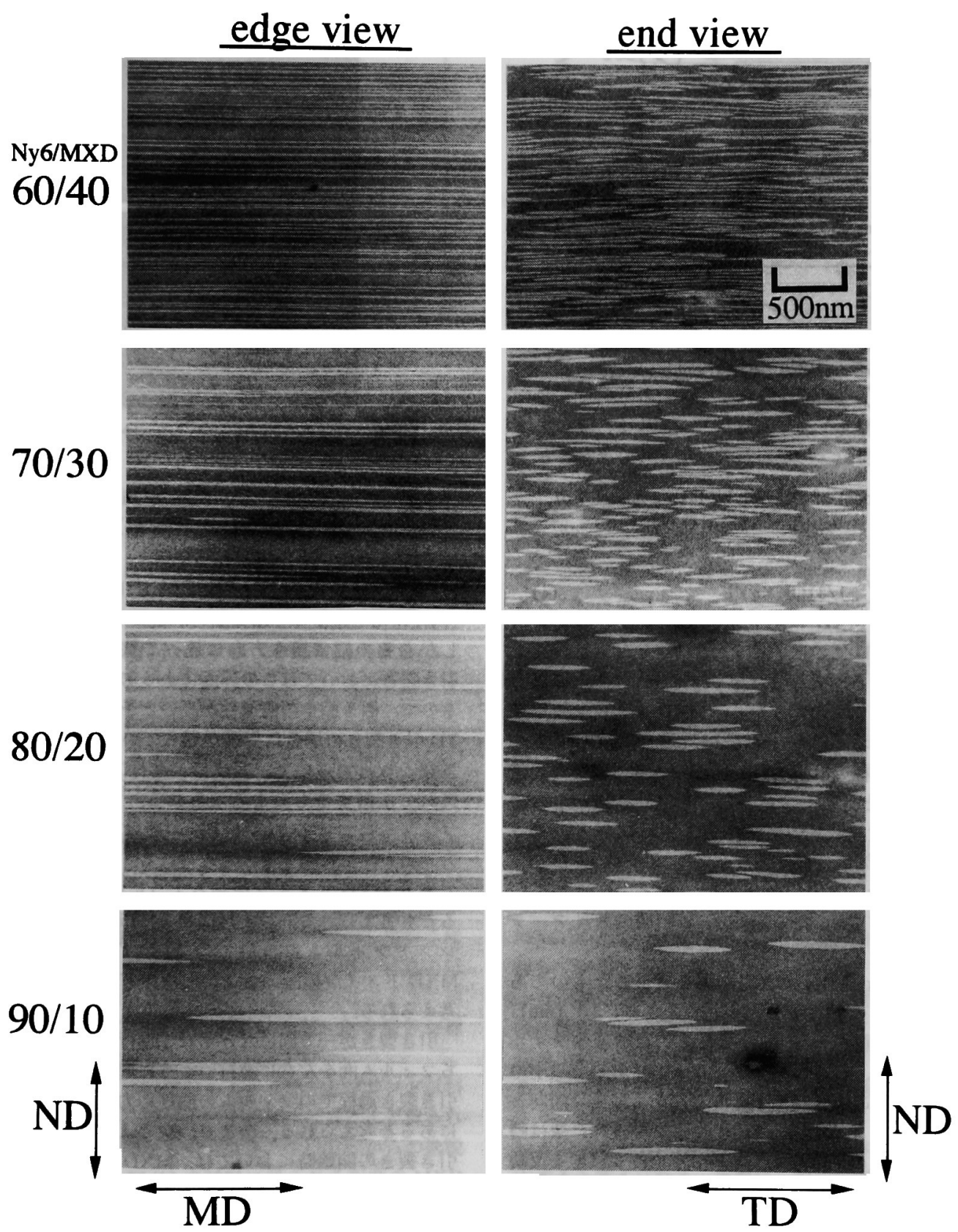

Fig. 6. TEM photographs of biaxially stretched blend films. MD, TD, ND denote the machine direction, transverse direction, and film normal direction, respectively. 

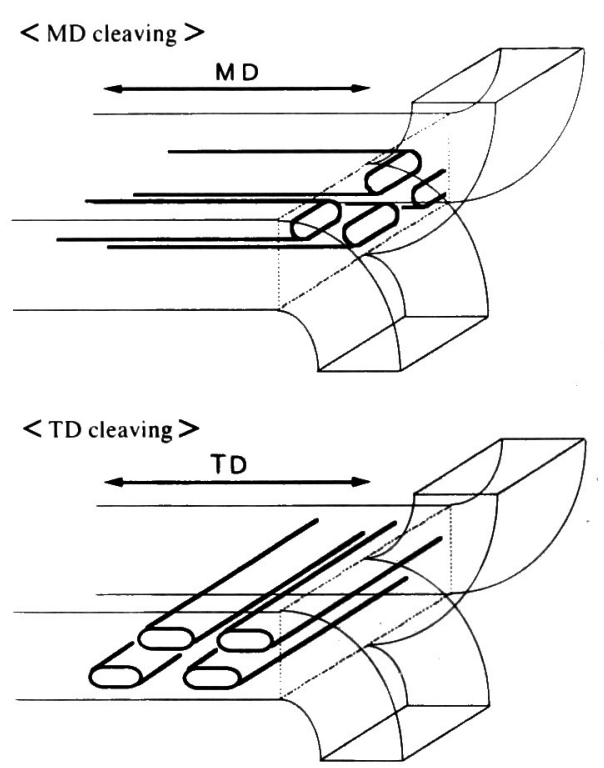

Fig. 7. Model of cleaving by taking account of the domain structure.

$$
I(q) \sim \exp \left\{(-1 / 3)(W \times q)^{2}\right\}
$$

ここで, $2 W$ はXDドメインをMDに長い扁平板状 としたときの TDでのドメインサイズ, $q$ は散乱ベクト 儿の絶対值である. 得られたデー夕を $\ln I v s . q^{2}$ の形で プロットし，グラフの傾きから，MXDドメインサイズ を評価した，なお，この方法は一般に知られているギ二 エプロットと同様の解析手法である. 下部に載せた同縮 尺の $V_{\mathrm{v}}$ 像写真と比較してみると, $\theta<15$ [degrees] の領 域は等方的な散漫散乱の影響が懸念される。一方， $\theta>$ 25 [degrees] の領域は散乱強度が弱くノイズの影響を受 けやすい，また(1) 式の適用範囲， $W_{q}<1$ を満たさな い. よって, $15 \leqq \theta \leqq 25$ [degrees] の領域の散乱デー夕 をフィッティングに用いた.

Fig. 10 はフィッティングの結果をまとめたものであ る. 縦軸はTDの MXD ドメインの大きさ; $2 W[\mathrm{~nm}]$, 横軸はNy 6 の重量分率 $\Phi_{N y 6}$ である. 二軸延伸フィル ムでは $\Phi_{\mathrm{Ny} 6}=0.7(\mathrm{Ny} 6 / \mathrm{MXD}=70 / 30)$ において最小の $2 W$ となった。この傾向は Fig. 6 の TEM 写真の傾向と よく一致した，すなわち，TEM 観察で得られた像は特 異点を映したものではなく，試料の平均的な状態を反映 していると言える.

\section{4 考察}

\section{1 引き裂き進行の直進性について}

Fig. 7 において, MD引き裂きの場合, 引き裂こうと する方向とドメインの長さ方向が一致する. そして長さ

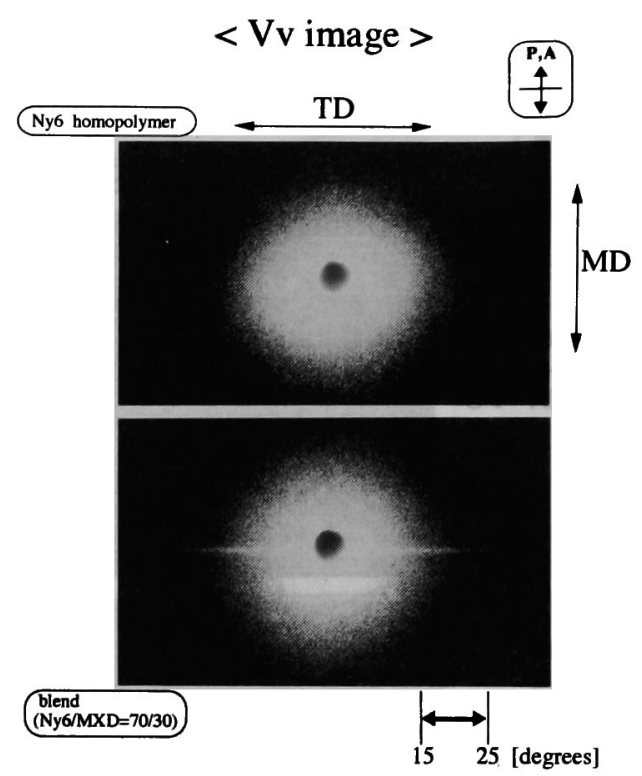

Fig. 8. Light scattering image of biaxially stretched blend films (parallel polarization, $V_{v}$ ).

方向には MXDドメインとNy 6 マトリックスの界面 （円柱にたとえるならば側面）がまっすぐに通っており， しかもその幅は長さ方向に比べて狭い。つまり，MD 引き裂きにおいてはこの界面によって裂け目が伝搬され るので, 引き裂きの直進性が高いと予想される. 一方, TD引き裂きの場合は界面が通っている方向と垂直に引 き裂こうとするので, 裂け目が進行方向から MD と 逸れて伝搬するあのと考えられる.すなわちブレンド フィルムにおける $Y_{\mathrm{MD}}$ と $\boldsymbol{Y}_{\mathrm{TD}}$ の差は, 試料中の界面の 方向異方性に起因すると考えられる．あるいは脆性成分 である MXDドメインを割るように裂け目が伝搬され るとも考えられる. いずれにせよ, Fig. 3, 4 におけるブ レンドフィルムについでの $\boldsymbol{Y}_{\mathrm{TD}}>\boldsymbol{Y}_{\mathrm{MD}}$ という結果は MXD ドメインの配向および形状異方性が原因であると 考えられる.

引き裂きが一方向にだけずれて進行する原因，すなわ ちフィルム面を左右に波打つように進行しない原因は， 引き裂き過程でのフィルムの曲げ応力のバランスの変化 にあると考えられる. つまり, 次のように推定される. 引き裂きの開始時においては, MXD ドメインに対して 引き裂き断面が界面の連続する方向に垂直にぶつかる. そして界面の影響でその方向がずれて, フィルム面が水 平から傾き, フィルムの曲げ応力のバランスが左右で崩 れる.このとき，例えば引き裂きが進行方向に対して右 に逸れたとすると, フィルムは，引き裂きがやや右寄り に進行しゃすくなると考えられる. ただし, ずれの程度 


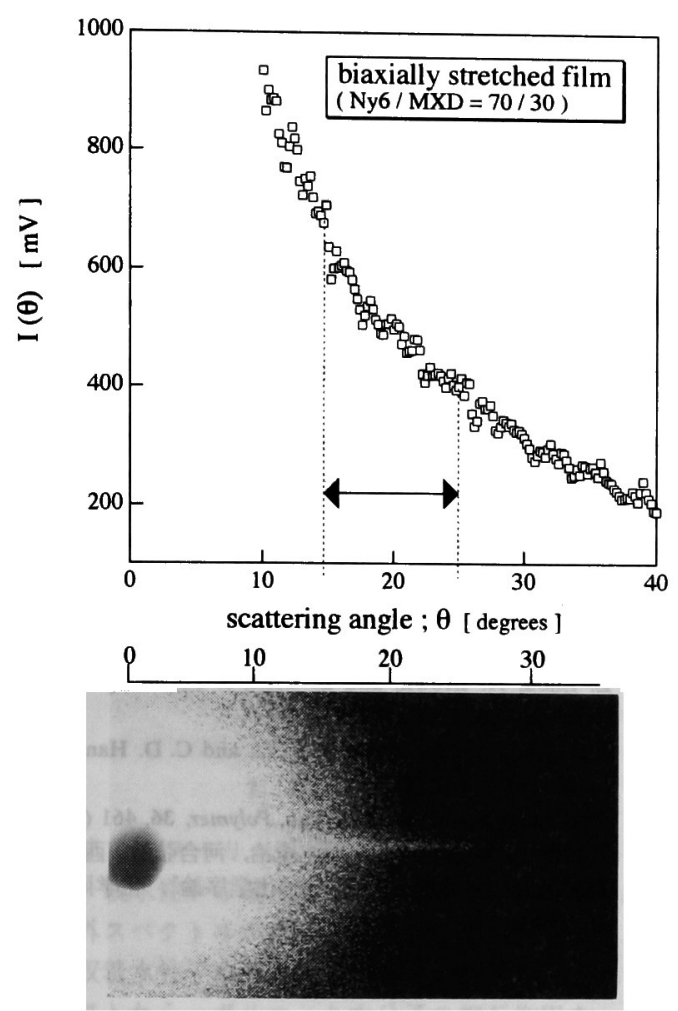

Fig. 9. Scattering intensity vs. scattering angle for a biaxially stretched blend film.

は界面の連続性に起因すると考えられる.

また, Fig. 5 に示すように, $\Phi_{\mathrm{Ny} 6}=0.6(\mathrm{Ny} \mathrm{6/MXD}$

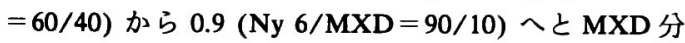
率が低下するに従って， $\boldsymbol{Y}_{\mathrm{TD}}$ が低下した.この結果は, 引き裂き断面を通過する MXDドメインの本数と関連 づけて，次のように説明することができる. Fig. 6 の TEM 写真から, 一定の空間内に存在する MXDドメイ ンの本数が, MXD 分率の低下に伴って減少している様 子が分かる. TD引き裂きの場合, edge view 写真の紙 面と垂直な方向に引き裂き断面を生じる．このときに横 切る MXD ドメインの本数が多いほど, 引き裂きが界 面の連続方向へ逸れたと考えられる.

しかし， $Y_{\mathrm{MD}}$ についてはホモポリマーとブレンド試料 の差は見られたが, 組成比による変化ははとんど見られ なかった．この結果から引き裂きの進行方向からの逸脱 は, Ny 6/MXD =90/10 の試料に見られる程度の MXD ドメインの本数でホモポリマーに比べてかなり減少し, それ以上ドメインの本数が増加してもほとんど変化しな かったと考えられる，あるいは，直進性の向上は測定誤 差程度であったと思われる.

また, ホモポリマーよりあブレンドの方が $Y_{\mathrm{TD}}$ の值

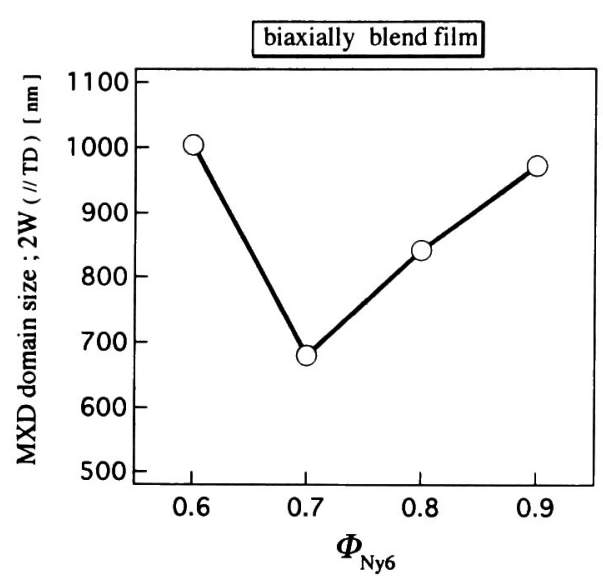

Fig. 10. MXD domain size (//TD) obtained by light scattering $v$ s. weight fraction of Ny 6.

が低い場合がある.これは, ドメイン構造の有無に起因 すると考えられるが, 詳細については更に検討が必要で ある.

\section{2 引き裂き荷重について}

Fig. 3, 5 のブレンド試料における $F_{\text {ave, TD }}>F_{\text {ave, MD }}$ とい う結果も, 基本的にはドメイン構造に起因すると考えら れる. MD引き裂きの場合, 長さ方向の MXDドメイ ンの連続性によって界面に沿って破壊が進行するため に, より小さい力で引き裂きを進行させることができた と考えられる. TD引き裂きの場合は, 界面あるいはド メインの連続する方向と垂直に引き裂くことになり， MD引き裂きに比べて余計に力を必要としたと考えら れる.

しかし，Fig. 5 に示すように， $F_{\text {ave, TD }}$ の組成による変 化は見られたが, MXDドメインの本数の変化と対応し ておらず, $\Phi_{\mathrm{Ny} 6}=0.7(\mathrm{Ny} 6 / \mathrm{MXD}=70 / 30)$ において最 大となった.つまり $F_{\text {ave, TD }}$ の組成による変化には, MXDドメインの配列および形状異方性以外の因子む関 与していると考えられる.

分子鎖配向の異方性む因子であると考えられる，例え ば，MDに分子鎖が配向しているとすると，MD引き 裂きでは引き裂き断面が分子鎖を横切る確率が減少す る. 反対に TD 引き裂きでは分子鎖を横切る確率が増大 する.よって, MD 配向度が増大するほど，MD引き 裂きに要する力は減少し, TD引き裂きに要する力は増 大すると考えられる. 実際に, 複屈折湘定においては, このような傾向が観察された. しかし, 一部の試料（あ るいは組成）で対応しておらず，引き裂き荷重の組成に よる変化には, 複数の要因が作用していると予想され る.

$F_{\text {ave, MD }}$ については組成比による変化は見られなかっ 
た。この結果から引き裂き荷重は, Ny $6 / \mathrm{MXD}=90 / 10$ 程度の MXDドメインの界面の連続性で Ny 6 ホモポリ マーに比べてかなり減少し，それ以上ドメインの本数が 增加してもほとんど変化しなかったと考えられる。 ある いは変化が測定誤差程度であったと思われる。

\section{5 結論}

本研究で用いた Ny 6/MXD二軸延伸フィルムは，引 き裂く方向により引き裂き荷重および直進性が異なっ た. そして, 同フィルムは内部に一定方向に配列した細 長いMXDドメインを有することが TEM 観察から分 かった．このようなドメインの形状異方性が引き裂き性 の異方性の主要因であると考えられる.

さらに，引き裂き性と内部構造のブレンド組成による 変化は, 引き裂き直進性の異方性は，MXDドメインの 形状および配向がその支配的要因であることを示唆する あのであった。しかし,引き裂き荷重の異方性は, 基本 的には MXDドメインの形状および配向に起因するが, その他の因子にも影響されることを示唆するものであっ た.

また，光散乱法によるドメインサイスの評価は電子顕 微鏡観察による結果と比較して良好な一致を示した。す なわち, 得られた TEM 写真は試料の内部構造の平均的 な状態を表していると言える.
文献

1) H.-K. Chuag and C. D. Han, J. Appl. Polym. Sci., 30, 165 (1985).

2) R. Greco, M. Malinconico, E. Martuscelli, G. Ragosta, and G. Scarinzi, Polymer, 28, 1185 (1987).

3) R. Greco, M. Malinconico, E. Martuscelli, G. Ragosta, and G. Scarinzi, Polymer, 29, 1418 (1988).

4) M. Lu, H. Keskkula, and D. R. Paul, Polymer, 34, 1874 (1993).

5) W. H. Jo, H. G. Kim, and S. H. Chae, Polym. J., 25, 1023 (1993).

6) Y. Takeda and D. R. Paul, Polymer, 32, 2771 (1991).

7) M. Shibayama, K. Uenoyama, J. Oura, S. Nomura, and T. Iwamoto, Polymer, 36, 4881 (1995).

8) 松本喜代一, 高分子学会編, “高分子加エワンポイントー 2", 共立出版, 東京 (1993).

9) M. Shibayama, S. Nomura, T. Hashimoto, and E. L. Thomas, J. Appl. Phys., 66, 4188 (1989).

10) Z. Zhou, N. Brown, and B. Crist, J. Polym. Sci., Polym. Phys. Ed., 33, 1047 (1995).

11) J. H. Han, C. Choi-Feng, D.-J. Li, and C. D. Han, Polymer, 36, 2451 (1995).

12) C. E. Scott and C. W. Macosko, Polymer, 36, 461 (1995).

13) 岡村誠三, 中島章夫, 小野木重治, 河合弘廸, 西島安則, 東村敏延, 伊勢典夫, “高分子化学序論”, 化学同人, 京 都 (1990).

\section{Mechanical Properties and Structure of Nylon 6/Aromatic Polyamide Blend Film}

Jun-ichi Oura*1, Mitsuhiro Shibayama*1, ${ }^{\dagger}$, Shinichi SakuraI*1, Shunji Nomura*1, and Takehiro Iwamoto*2

${ }^{* 1}$ Department of Polymer Science and Engineering, Kyoto Institute of Technology (Matsugasaki, Sakyo-ku, Kyoto, 606

Japan Tel: 075-724-7893, Fax: 075-724-7800, e-mail: mitsu@ipc.kit.ac.jp)

*2 Packaging Products $R$ \& D Center, Idemitsu Petrochemical Industry Co., Ltd. (Kabuto 841-3, Shirahama-cho, Himeji, 672 Japan)

Recently, much attention has been paid to nylon 6 ( $\mathrm{Ny} \mathrm{6)}$ and poly ( $m$-xylene adipamide) (MXD) blend films because of their high gas barrier properties. When the blend film is biaxially stretched, it exhibits a mechanical anisotropy, i.e., a directional dependent cleaving. We report here the cleaving property of Ny 6/MXD blend films. The difference in the force and the deviation of cleaving parallel and perpendicular to the machine direction (MD) was studied as a function of the composition. It was found by electron microscopy that the blend films had a plate-like structure consisting of MXD domains. The domain is highly oriented along MD. The difference of cleaving anisotropy is partially due to this domain structure.

KEY WORDS Polymer Blend / Cleaving Property / Domain Structure / Nylon 6 / Aromatic Polyamide /

Poly ( $m$-xylene adipamide) / Light Scattering /

(Received March 26, 1996: Accepted April 12, 1996)

[Kobunshi Ronbunshu, 53(7), 453-460 (1996)]

\footnotetext{
${ }^{\dagger}$ To whom correspondence should be addressed.
} 